\title{
Financial Resources Management Information System of Flagship University Projects
}

Chekotilo E.Yu. ${ }^{1, *}$ Abramkina D.A. ${ }^{1}$ Kichigina O.Yu. ${ }^{2}$

\author{
${ }^{1}$ Samara state technical university \\ ${ }^{2}$ Saint Petersburg state marine technical university \\ *Corresponding author.Email: e_chekotilo@mail.ru
}

\begin{abstract}
One of the priorities for development of modern universities is the transition to project management. This article presents the premise for the formation of a project management system at university. In particular, the subsystem of financial resources management of university projects is considered in the framework of implementation of Flagship Universities Development program. The mechanism of analytics support of project financing is presented. The creation of financial resources management information system of Flagship University's Development Program projects on the basis of the corporate information system became possible due to this model. The system automates the processes of planning the expenditure of the Development Program funds for action item within the framework of university strategic projects. At the same time, all accompanying the project implementation financial risks are taken into account at the planning stage as much as possible. The system provides operative monitoring of project implementation not only in terms of expenditure budget and co-financing funds, but also in terms of achieving headline indicators and targets. The proposed system might be an effective tool for improving the quality of financial management of the organizations.
\end{abstract}

Keywords: project financing management, information and analysis system, University's Development

Program

\section{INTRODUCTION}

In 2016, the World Bank published a report on world development.The topic of this report was the expansion of digital technologies, analysis of risks and benefits of its use [1]. The authors note that today the world community is experiencing the greatest information and communication revolution in the human history, and it leads irreversibly to the formation and development of a new type of economy in countries - the digital economy. The development of information and communication technologies, the widespread use of big data analysis technology, the introduction of new decision-making algorithms, automation and robotics leads a new premise for changes in the economic systems of countries [2]. Now, one of the factors for increasing the efficiency and competitiveness of each company separately and the state in the world arena is the digitalization of all processes.

In 2017-2018, the development of digital technologies was approved in the "Strategy for the Development of the Information Society of the Russian Federation for 20172030" and in the national project "National Program" Digital Economy of the Russian Federation" as a priority task of the Russian Federation [3 - 4]. A new ecosystem of economy is formed by 2030 as a result of its implementation in Russia. This ecosystem will be based on effective interaction by means of using an electronic technologies, infrastructure and services in order to ensure the economic growth of the country and improve living standarts. Thus, the digital economy is not a separate industry, but the basis of a qualitatively new model of business, trade, logistics, production, changing the format of communications.

The level of development of the digital economy is characterized by a number of criteria. It is worth to highlight the rejection of document circulation on physical media in favor of electronic media, which helps to simplify the collection, storage and analysis of information, accelerates all business processes; reduced human role due to business process automation, digital infrastructure, as well as the adaptation of enterprise management systems to the requirements of the digital economy among these criteria. At the same time, digital transformation in an organization needs to be carried out on the basis of a holistic approach. The most important aspect here is not a digitization of information, but an adaptation of organizational structures to the application of IT-solutions in management, and, first of all, big data [5]. There is a needs to change existing management technologies in organizations, that forcing them to look differently at different methodologies, in particular project management.

Today, using of project management has become the most common way for many companies in different spheres of activities. Project management methodologies enable 
organizations to be flexible and operate in a highly uncertain environment. The main disadvantage is the complexity of monitoring the process and the necessity for developing aT explicit system of up-to-date information exchange between all stakeholders of the project. Digitalization accelerates business processes. In this case, the necessity for responding more quickly to changing conditions in the internal and external environment is increased, and necessity for adjustment the usual methods of project management is arisen. Implementation of digital technologies radically transform all processes of project management. It provides the basis for faster, flexible decision-making process in real time, reduces the time of project implementation, reduces risks of quality reduction of implemented projects. Infrastructure management is to be organized in a particular manner with the ability to track resources at each life-cycle stage. Production and management processes automation, ongoing project monitoring, and openness of project data to all stakeholders of the project provide for minimization of resources lack risk [6].

Rules and tools of project management are used not only in private companies, but also in public institutions. Thus, in 2016 the project office under the President - the Council for Strategic Development and Priority Projects has been established, the process of state institutions transition to project management has been launched. Universities are no exception.

The modern university operates in a rapidly changing environment, as any other organization. And it is exposed to various risk factors. Strategic decision-making in resource constraints forces university management to use project management tools. The specificity of the university consists in point that it is a separate class of complex socio-economic systems. It is have an ability to organize itself and have a large number of external ties, as well as implementing socially important projects. The majority of Russian universities have already completed the transition to a fundamentally new management system based on project management. But today every university has to go through a digital transformation, as it is reflect the rapid development of society associated with the entry of digital technologies into all processes, regardless of the chosen strategy.

First of all, digital transformation of the university involves a transition to a new model of university basic processes implementation - educational and scientific based on the application of high quality IT-solutions. But the formation of a digital university cannot be limited to the implementation of information technologies into the educational process. This transformation involves the implementation of information technology into all internal processes of university management and it is a significant cultural and organizational change.

University's priority task is to incorporate digital technologies into the financial management process, as it is given the limited resources, as well as the many statutory limit associated with spending funds as per their intended purpose. Creation of an information system of an effective financial management on the basis of project management instruments implemented by universities allows controlling financing, ensuring economic efficiency and openness of decisions taken.

In 2015, the Ministry of Education and Science of the Russian Federation initiated a Program of creation and development of Flagship Universities [7]. One of the conditions for build up of Flagship Universities' roadmaps was using of project management methodology to implement all the changes. Six direction of universities modernization were formed: educational activities, science and innovation, development of human capacity, material and technical equipment, social and corporate development, interaction with the region. All the activities were formed in the project logic within the framework of these blocks. For example, the development program of Samara State Technical University (hereinafter - SamSTU) was represented by 37 projects.

The priority task of the Flagship University was its inclusion in implementation of the Strategy of socioeconomic development of the region. In order to achieve this goal, a new format of implemented in the interests of the region strategic projects was developed in 2017 by the Ministry of Education and Science of the Russian Federation. Strategic projects were to cover all directions of University's transformation in a varying degree. At the same time, the projects of the University Development Program, as a Flagship University (hereinafter - the Development Program) were included in the portfolios of developed strategic projects either in part or in whole.

Declared projects were fundamentally different from each other not only by the theme and set of tasks, but also by the list of partners involved in a work, as well as stakeholders. The concerned parties were representatives of regional authorities, industrial enterprises, scientific and educational organizations, public organizations, residents of the region. For example, in SamSTU, strategic projects include:

- the "My City" project - planning and designing of infrastructure and the urban environment, creation of the Center of engineering restoration of cultural heritage monuments of the region.

- the "Seventh Processing" project - development a petrochemical cluster in the region, creation of new industrial platforms.

- the "Ground of Technologies" project - technological modernization of the regional industrial enterprises, preparation and retraining of highly qualified staff by the industrial sector order.

- the "Territory of Life" project - creation of a system of steady improvement of population life quality on the basis of the high nature protection, pharmaceutical and food technologies.

Diverseness, variety and interdisciplinarity of projects, as well as the specifics of the organization of project activities in an educational budget institution, led to the need to transform and adapt existing technologies of project management. Otherwise, the process of project methodology implementation into universities would be only terminological [8]. Within the framework of the 
Development Program, SamSTU implements a package of activities "Development of the project management system". In this work, we will focus on the project financial resource management subsystem.

\section{METHODOLOGY OF INVESTIGATION}

Analysis of scientific literature related to digitalization of the main business processes of the University [9 - 10], showed that researchers mainly focus on the educational component of the University's activities. Promising developments are considered a corporate systems of the University, covering all the processes of the organization's life. However, experts disagree on the use of automation tools. The choice is between ready-made solutions, including open source software and software developed by the University. At the first case, it is often necessary to rewrite the system to suit the specifics of the University, and in the second - an effective solution can only be considered a single corporate information system of the University, which allows you to get rid of the "patchwork" of existing analytical systems at the University [11]. A significant circumstance is also the fact that most Russian universities are forced to work in conditions of a lack of financial resources. At the same time, they have the potential to create, support and adapt to the constant changes of their own information systems.

As noted earlier, the task of developing an information system for managing University projects is one of the most actual problems in the modern realities of University transformation. At the same time, the project management system should include not only a set of software and hardware solutions, but also a set of methodological and regulatory documents. In our opinion, one of the key subtasks of creating an effective project management system is the problem of developing a system for managing the financial resources of strategic University projects as a part of an unified corporate information system. Before starting to digitalize the investigated process, it is necessary to describe the model of this business process [12].

A special feature of the financial support for the development programs of Flagship universities is not only the allocation of subsidies from the Federal budget, but also mandatory financial support for projects from the region, as well as co-financing of action item from the University's own funds. Co-financing from the region and the University's own funds are received fairly evenly throughout the entire period of the Development Program implementation. Due to the specifics of financing the educational system in Russia, funds from the Federal budget are transferred only in the third - fourth quarter and must be disbursed by the end of the reporting year. Uneven allocation of funding has become a significant problem for the development of the project management system, since financial accounting is the accounting of completed operations and is mainly managed only in fact. The University faced difficulties in conducting procurement procedures - with the acquisition and delivery of equipment, software, using the services of third-party legal entities and individuals and etc. The lack of competencies necessary for effective budgeting of project activities, and uncertainty in the division of responsibility between the financial and economic departments of the University also hindered the efficiency of management decisions. Therefore, an urgent task for the University has become the formation of a system for organization and managing the financing of Development Program projects. The core of the designing system has become the project management Center. In addition to the functions of managing the University Development Program as a whole, it was given the functions of project Finance management, management accounting, and financial and economic analysis. This structure is the carrier of the management projects methodology of the Development Program, which is able to centrally administer all processes, as well as provide technological support and control of their implementation.

To ensure further automatisation of the financial and economic support processes of project activities, a number of regulations have been developed that systematize and regulate these business processes. Figure 1 shows the procedure for information and analytical support for financing Development Program projects.

In accordance with scheme:

1. Vice rectors in charge of the University main activities form a roadmap for the implementation of the Development Program for the next year. This takes into account the planned amount of co-financing of events and the amount of allocated funds from the Federal and regional budgets. Specifics of planning are that the distribution of funding between individual areas and enlarged blocks of activities in the current period may differ significantly from the previous period. Thus, in the first year of the Development Program, the main amount of budget funds was allocated to educational projects. In the future, after the formation of strategic projects, Federal funding was distributed to scientific and innovative projects, and regional funds were received to strengthen the material and technical equipment of the University. In addition, educational initiatives launched in 2016, such as the creation of interdisciplinary project teams, attracted the attention of investors, which means additional income from the region's funds. Taking into account all factors, the project management Center develops a detailed roadmap and a detailed plan for the implementation of project activities for the year. In this case, it is possible to make adjustments in the course of performing work on projects.

2. Project managers form the terms of reference for a work plan implementation for each specific block of activities. At the same time, the goals and tasks are worked out, and activities are detailing, indicating the planned results and performers. In addition, the results of preliminary estimates are mandatory. As mentioned earlier, the University's projects are quite diverse, so each of them has its own characteristics of financing: for ones the main expenses fall on the salary Fund, travel expenses and scholarship Fund, for others - it is quite complex procurement procedures of goods and services, for the 
third - it is the organization of events, including involving and further paying for the services of experts and specialists from various enterprises. At the same time, due to the specifics of the project activities of universities, it is necessary to foresee and minimize all possible risks at the planning stage. Including the likelihood of a drastic change in the financing plan by expenditure items.

3. Proposals of project managers are sent to the project management Center. The center's employees analyze and evaluate the compliance of the project goals and objectives with the goals and objectives of the Development Program. They also evaluate the declared performance, adequacy and measurability of indexes and indicators, and verify the volume and sources of funding. The project management Center selects and invites independent experts for each priority area of the University's activities. In the future, it organizes meetings of expert councils in the areas to decide on the feasibility of implementing each project.

If the expert council makes a positive assessment for the complex of project activities, the project manager forms a planned budget for the expenditure of funds, detailed by type and source of expenditure. For projects that are part of the strategic projects of the University, a summary estimate documentation is issued. At the same time, the project management Center provides consulting and methodological support for this activity. The developed documentation is subject to approval by the relevant vice rectors or heads of relevant departments, economic planning, procurement and accounting departments. After that, a summary detailed planning estimate for all projects of the Development Program for the current year is formed and approved by the rector.

5. Further, all expenditure operations are performed by the accounting department in accordance with the approved and agreed with the economic planning department estimates. The basis of activity is memos that are formed by work managers in conjunction with the project management Center. The forms of documents and their consideration procedure has approved by internal regulations. The project management Center provides formation and execution of documents on the expenditure of Development Program funds. These documents include memos, technical specifications for external procurement, civil contracts, invoices, acts, etc.

6. Procurement procedures of goods, works and services are carried out in accordance with the procedure established in the University, on the basis of documents of the current legislation. Based on the results of the current year, the project management center generates an actual estimate for the expenditure of funds for the Development Program of the reference University.

For automatisation and optimisation the work of the project management Center, an information system "Managing the implementation of the development Program" was designed on the platform of the University's corporate automated information system. One of the modules of this system is the subsystem for managing financial resources of projects.

\section{RESULTS}

Information system of financial resources management provides digitalization of all management cycle stages: planning, accounting, control and analysis. It is capable of demonstrating a complete financial view of projects, from rapid data acquisition to complex analysis and presentation. Thus, controllability and transparency of cash flow is guaranteed.

The major feature of this system is forming and controlling the expenditure side of the project budgets.

Analysis information system solves the tasks of communication and document management, as well as the tasks of forming the archive and knowledge base of the University projects in addition to planning resources and deadlines, analysis and operative monitoring of implementation of individual project and project portfolios in terms of results and target indicators.

The system implements a multi-level organizational structure of users. To ensure data security, the procedure of creating personal rooms has been implemented in the system with distinction between statuses, roles and access rights to information. It is possible to set up at an automatized working place a system of prompt notification of risks arising in case of exceeding the terms, scope or cost of works, as well as a number of other indicative indicators.

As noted earlier, the system has implemented three major processes: project planning; organization and execution; monitoring the implementation and achievement of results and indicators. Let us consider each of these components in detail.

At the planning and organization of works stage, a project tree, sub-projects, blocks of measures and schedules of its implementation are formed. Then responsible officers are appointed, resources are allocated and budgets are prepared detailed by expense item and time period. An upper bound of different types of costs is created for each project. Summary balance sheets for complex strategic projects are drawn up on the basis of consolidation. It is possible to readjust the estimated documentation at the purpose of changing sub-projects budgets expense items and sources of expenditure both within projects and between interrelated projects and project portfolios.

During the implementation of projects, information on the work performed and results achieved are included to the schedule, as well as logistical and financial resources used. It is possible to unhide indicators status. The status describes the current ratio between the planned, prediction and actual indicators. Analytical reports and other reporting documents on the implementation of the Development Program are automatically generated based on this information. Besides, it is available to load supporting documents into the system at all stages of works. An Electronic Document Processing Request System organized within the system declines considerably a management decision-making time. 


\begin{tabular}{|c|c|}
\hline \multicolumn{2}{|c|}{ Documents of Development Program } \\
\hline & \multirow[b]{2}{*}{$\begin{array}{l}\text { Vice rectors } \\
\text { Project } \\
\text { management } \\
\text { Center (PMC) }\end{array}$} \\
\hline $\begin{array}{l}\text { Development of a } \\
\text { Roadmap for the } \\
\text { current year, accounting } \\
\text { funds from all sources }\end{array}$ & \\
\hline \multicolumn{2}{|c|}{$\begin{array}{l}\text { Detailed Roadmap with action plan for the } \\
\text { current year }\end{array}$} \\
\hline \multicolumn{2}{|l|}{4} \\
\hline $\begin{array}{l}\text { Generation of Terms of } \\
\text { reference for } \\
\text { implementation of the } \\
\text { work plan for each } \\
\text { activity }\end{array}$ & $\begin{array}{l}\text { PMC } \\
\text { Project } \\
\text { managers }\end{array}$ \\
\hline \multicolumn{2}{|c|}{$\begin{array}{l}\text { Terms of reference for activities with } \\
\text { indication of goals and objectives, } \\
\text { planned results, work performers, } \\
\text { preliminary estimates }\end{array}$} \\
\hline 1 & \multirow[b]{2}{*}{$\begin{array}{l}\text { PMC } \\
\text { Expert } \\
\text { councils }\end{array}$} \\
\hline $\begin{array}{l}\text { Assessment of stated } \\
\text { goals, targets, } \\
\text { performance indicators, } \\
\text { levels and sources of } \\
\text { funding for activities }\end{array}$ & \\
\hline \multicolumn{2}{|l|}{1} \\
\hline \multicolumn{2}{|c|}{$\begin{array}{l}\text { Planned expenditure project estimates } \\
\text { by type and source of expenditure }\end{array}$} \\
\hline \multirow{2}{*}{\multicolumn{2}{|c|}{$\begin{array}{l}\text { Vice rectors } \\
\text { Economic planning } \\
\text { department (EPD) } \\
\text { Procurement } \\
\text { department } \\
\text { Accounting } \\
\text { department }\end{array}$}} \\
\hline & \\
\hline \multicolumn{2}{|c|}{$\begin{array}{l}\text { Approved detailed planning estimates for the } \\
\text { current year }\end{array}$} \\
\hline$T$ & \multirow{3}{*}{$\begin{array}{l}\text { PMC } \\
\text { EPD } \\
\text { Procurement } \\
\text { department } \\
\text { Accounting } \\
\text { department }\end{array}$} \\
\hline $\begin{array}{l}\text { Expenditure activities, } \\
\text { procurement } \\
\text { procedures for goods, } \\
\text { works and services }\end{array}$ & \\
\hline 1 & \\
\hline $\begin{array}{l}\text { Actual expenditure esti } \\
\text { year }\end{array}$ & r the current \\
\hline
\end{tabular}

Figure 1 Procedure for information and analytical support of Development Program projects financing 
Progress monitoring of action item is monitored by system administrators for both individual projects and the project portfolio. Administrators are employees of the project management Center primarily, as well as representatives of relevant structures, including economic planning, procurement and accounting departments. Works are carried out at all stages of the annual work cycle. Actual results of performance are assessed in accordance with the schedule and estimates. The final cost of the project is determined at the completion stage.

The flexible reporting system allows generating consolidated information on the implementation of individual projects and on the Development Program in whole, making management decisions on the basis of complex analysis and to use the experience in the future.

\section{DISCUSSION}

The developed system is a self-contained, replicable software product. It can be deployed on any platform. However, it does not require special settings or installation of additional software.

It is sufficient to have any Internet browser, and there are no special requirements for administrator qualifications. This system is integrated into the University's corporate information environment.

There is an advantage of the proposed information system over other products on the software market. This software is oriented to the specificity of tasks and processes of project management in universities. Namely, the focus on projects financed from Federal and Regional budgets. This software may be interesting to universities participating in implementation programs of Flagship Universities and Universities top 5-100. In addition, analogues that operate the proper functionality of the described system and are able to adapt to current tasks are often an order of magnitude more expensive and available only to large corporations.

Implementation of the presented information system provides an opportunity to optimize the processes of allocation of financial resources along with other University's mechanisms of income and expenditure generation. And this allows the University to stably occupy high positions in the rating of universities financial management efficiency.

The rating is built on the basis of three blocks of indicators analysis characterizing the quality of planning of financial and economic activity, its financial stability and strategic indicators. The utmost importance in the integral indicator is given to blocks of financial planning quality and sustainability - it is provided the University with a stable high place in the rating. Despite the aspect of special purpose funding, with funds receiving in the second half of the year and it is has to be spent in the same year, the University managed to reduce to zero the unjustifiable balances of funds, as well as minimize the difference between planned and actual values of income and expenditure - the maximum difference between plan and fact was less than $3 \%$ according to the results of 2017 -
2018. This has been made possible by using of an information system.

\section{CONCLUSION}

To effective manage the implementation of University projects and individual activities, it is necessary to formalize as much as possible and digitalize the processes of planning, monitoring and evaluation of the implementation of projects. A key process is managing of the University projects and project portfolios financial flows.

To process automation, it has been proposed project financial resources management information system, developed and implemented in SamSTU. The system is an effective tool for making and executing management decisions, planning, coordinating and monitoring the execution of works at different stages of the project life cycle. It is a complex of normative, methodological bases and software. Proposed system relates to digital services of the University's corporate information environment. This information environment is the core of the digital infrastructure of the University, and it is able to ensure effective management of all business processes. The development of an integrated information space is a key stage of University digital transformation. This transformation allows using of end-to-end digital technologies in management decisions. This contributes to the efficiency, and therefore competitiveness, of the University, as well as the regional system of higher education.

\section{REFERENCES}

[1] World Development Report 2016: Digital Dividends, International Bank for .Reconstruction and Development / The World Bank, 2016

[2] R. Bukht, R. Heeks Defining, Conceptualising and Measuring the Digital Economy, in: International Organisations Research Journal, 2018, vol. 13, no 2, pp. 143-172. DOI: https://doi.org/10.17323/1996-78452018-02-07

[3] President of Russian Federation decree № 203 of may 09, 2017 «About strategy of information society developing in Russian Federation on 2017-2030»

[4] National project passport «National program "Digital economic of Russian Federation" (confirmed by Presidium of the Presidential Council of Russian Federation by strategy development and national projects, protocol N 16 of December 24, 2019)

[5] M. Fischer, F. Imgrund, Ch. Janiesch, A. Winkelmann, Strategy archetypes for digital 
[9] V.A. Larionova, A.A. Karasik, Digital transformation of universities: notes on the global conference edcrunch ural on technologies in education, in: University Management: Practice and Analysis, 2019, 23(3), pp. 130-135

[10] Z.K. Kurbanova, Project management features in the conditions of the Russian economy digitalization, in: Teoriya i praktika servisa: ehkonomika, sotsial'naya sfera, tekhnologii, 2019, 3(41), pp. 19-23

[11] N. Fedyakova, Improving management information systems at a higher educational institution, in: Integratsiya obrazovaniya, 2016; 2(20), pp. 198-210. DOI: https://doi.org/10.15507/19919468.083.020.201602.198-210

[12] E. Chekotilo, D. Prosvirina,O. Kichigina, Analysis and information financial management system for flagship university's development program, in: Modern Science: actual problems of theory and practice, series: Natural \& Technical Sciences, 2019, 8, pp. 136-139 